\title{
PERMINTAAN KEDELAI INDONESIA
}

\author{
Septi Rostika Anjani \\ email : septirostika@gmail.com
}

\begin{abstract}
ABSTRAK
Penelitian ini bertujuan untuk menganalisis faktor yang mempengaruhi permintaan kedelai di Indonesia. Metode penelitian menggunakan analisis deskriptif melalui data sekunder yang meliputi harga kedelai lokal dan kedelai impor, harga ayam, pendapatan perkapita, tingkat inflasi dan pemberlakuan tarif impor periode tahun 1980 sampai dengan tahun 2013 yang bersumber dari Badan Pusat Statistik dan berbagai sumber lainnya. Estimasi fungsi permintaan menggunakan analisis regresi linier berganda yang ditransformasi dalam bentuk logaritma.

Hasil analisis regresi menunjukkan bahwa secara simultan variabel independen berpengaruh signifikan terhadap variabel dependen dengan nilai $\mathrm{R}^{2}$ sebesar $65,1 \%$. Secara parsial, harga daging ayam, pendapatan perkapita, dan tingkat inflasi masing-masing berpengaruh signifikan terhadap permintaan kedelai. Sedangkan harga kedelai lokal, harga kedelai impor dan tarif impor tidak berpengaruh secara signifikan terhadap permintaan kedelai.
\end{abstract}

Kata Kunci: analisis permintaan, elastisitas, kedelai

\begin{abstract}
This study aims to examine the factors which influencing the demand of soybean in Indonesia. The basic method used in this study is descriptive analysis with secondary data which includes the prices of local soybean, the prices of imported soybean, the prices of chicken meat, income per capita, inflation rate, and the imposition of import tariff in year period 1980 to 2013 sourced from Badan Pusat Statistik (BPS) and other sources. Estimation of demand function using multiple linear regression analysis were transformed into logarithm.

The result of regression anlysis showed that simultaneously independent variables significantly influence the dependent variable with $R^{2}$ value is $65,1 \%$. Partially, the prices of chicken meat, income per capita, and inflation rate has significantly influence on demand of soybean. While the prices of local soybean,the prices of imported soybean and import tariff has no significantly influence on demand of soybean.
\end{abstract}

Keywords: demand analysis, elasticity, soybean

\section{A. Pendahuluan}

Indonesia merupakan salah satu negara agraris terbesar yang memiliki kekayaan alam dimana salah satu diantaranya adalah sektor pertanian. Di negeri agraris, pertanian memiliki peran yang sangat vital terhadap pertumbuhan permintaan domestik bagi produk-produk dari sektor ekonomi lainnya. Keadaan ini menuntut kebijakan pemerintah pada sektor pertanian disesuaikan dengan keadaan dan perkembangan yang terjadi di lapangan dalam mengatasi berbagai persoalan yang menyangkut kesejahteraan bangsa. Sejak awal, pengembangan sektor pertanian dianggap strategis di Indonesia. Hal ini disebabkan karena wilayah daratan indonesia yang sangat luas dan ditunjang oleh struktur geografis yang beriklim tropis sehingga sangat mendukung untuk pembudidayaan berbagai komoditi pertanian, salah satunya 
adalah kedelai. Sejak perdagangan kedelai lepas dari kontrol BULOG pada tahun 1991, impor kedelai meningkat sangat pesat (Sudaryanto dan Swastika,2007). Produksi kedelai dalam negri saat ini hanya mampu memenuhi sekitar $30 \%$ konsumsi domestik, sedangkan sisanya harus diperoleh melalui impor. Impor kedelai diperkirakan akan makin besar pada tahun-tahun mendatang, karena adanya kemudahan tataniaga impor sebagaimana yang telah disebutkan diatas bahwa dihapusnya monopoli BULOG sebagai importir tunggal serta dibebaskannya bea masuk dan pajak pertambahan nilai (PPN) kedelai. Disamping itu, negara eksportir kedelai terbesar dunia, seperti Amerika Serikat, juga menyediakan subsidi ekspor sehingga merangsang importir kedelai di Indonesia untuk memanfaatkan fasilitas itu.

Melihat semakin besarnya permintaan dalam negeri yang tidak dapat dipenuhi oleh produksi dalam negeri menuntut pemerintah untuk mengambil langkah impor guna menstabilkan keadaan pasar. Peningkatan jumlah impor dapat dilihat pada tabel. 1 yang menggambarkan keadaan impor pada tahun terakhir.

Tabel 1. Perkembangan Impor Kedelai Indonesia Tahun 2009

\begin{tabular}{|c|c|c|}
\hline Tahun & Jumlah(ton) & Nilai(US\$) \\
\hline 2009 & 1.314 .759 & 621.397 \\
\hline 2010 & 1.742 .759 & 821.234 \\
\hline 2011 & 2.088 .618 & 1.244 .307 \\
\hline 2012 & 5.747 .322 & 3.224 .915 \\
\hline 2013 & 5.319 .903 & 3.061 .677 \\
\hline 2014 & 5.764 .694 & 3.367 .977 \\
\hline
\end{tabular}

Sumber: FAO (2012) dan Deptan (2015), diolah

Besarnya permintaan dalam negeri membuat fluktuasi impor yang cenderung meningkat dari tahun ke tahun.Fluktuasi peningkatan terbesar terjadi pada tahun 2012 yang mana jumlah impor meningkat lebih dari 100 (100) persen. Hal ini memperlihatkan bahwa Indonesia menjadi salah satu negara importir kedelai terbesar di Asia Tenggara.

Pada tahun 2012, Kementrian pertanian telah meluncurkan dalam upaya mempercepat peningkatan produksi kedelai nasional.Kegiatan dan kebijakan yang terkait dengan kegiatan tersebut antara lain adalah peningkatan produksi, perluasan areal tanam,percepatan penyediaan benih dan stabilisasi harga (Direktorat Pangan dan Pertanian).

Dewasa ini, penanganan program kedelai masih relatif rendah bila dibandingkan dengan usaha peningkatan produksi bahan pangan pokok lainnya seperti padi dan jagung. Keterpaduan antara penyediaan sarana produksi, penyuluhan dan teknologi yang sesuai atau teknologi tepat guna, serta partisipasi petani dalam peningkatan produksi masih lemah. Semakin meningkatnya industri pengguna bahan baku kedelai semakin turut pula mendorong tanaman inimenjadi komoditas strategis karena konsumen kedelai terdiri dari lapisan masyarakat terbesarMulai 1970-an konsumen tahu tempe meluas tidak hanya di pulau Jawa, tetapi ke seluruh pelosok indonesia. Perpindahan penduduk dari pedesaan ke kota-kota besar di seluruh indonesia juga mendorong berkembang pesatnya industri tahu tempe di kota untuk penyediaan lauk yang merupakan sumber protein dengan harga yang sangat terjangkau bagi masyarakat kota termasuk bagi yang berpenghasilan rendah.Perkembangan industri peternakan dan pakan yang menggunakan bungkil 
kedelai sebagai sumber utama protein juga mendorong laju peningkatan permintaan kedelai. Tujuan dari penelitian ini adalah untuk faktor yang mempengaruhi permintaan kedelai di Indonesia.

\section{B. Rumusan Masalah}

Bagaimana permintaan kedelai di Indonesia?

\section{Tujuan Penelitian}

Untuk mengetahui permintaan kedelai di Indonesia?

\section{Landasan teori}

Permintaan kedelai menunjukkan kenaikan yang cukup besar seiring dengan pertambahan jumlah penduduk dan pendapatan masyarakat. Namun, disisi lain kemampuan produksi kedelai didalam negeri belum mampu mencukupi kenaikan permintaan tersebut (Manurung,2002).

Ketidakmampuan kedelai lokal untuk memenuhi kebutuhan kedelai negeri menyebabkan pasokan kedelai negeri bergantung pada impor kedelai. Ketergantungan yang semakin besar pada impor tentu saja merugikan industri pengolahan kedelai terutama jika harga pangan dunia menjadi sangat mahal akibat stok menurun. Hal ini terjadi karena harga yang berlaku pada harga kedelai internasional (Y Rante, 2013). Besarnya ketergantungan terhadap kedelai impor tersebut menyebabkan harga kedelai dipasar cenderung fluktuatif dan sulit untuk dikendalikan oleh instansi terkait. Pada hakikatnya, impor tidak hanya tergantung pada jumlah produksi atau pun pendapatan. Ada faktor lain yang juga mempengaruhi seperti selera dan preferensi konsumen, daya saing produksi dalam negeri, dan sebagainya. Adanya perubahan faktor-faktor tersebut akan menggeser fungsi impor. Seperti inflasi yang terjadi di dalam negeri akan menyebabkan daya saing menurun, maka impor akan cenderung naik dan kurva impor bergeser ke atas (Nopirin, 2009).

\section{E. Metode Penelitian}

\section{Ruang Lingkup Penelitian}

Untuk menganalisis permintaan kedelai di Indonesia maka variabel dalam penelitian ini dibatasi hanya pada variabel harga kedelai lokal, harga kedelai impor, harga daging ayam, pendapatan perkapita, tingkat inflasi dan tarif impor sebagai variabel independen dan variabel permintaan kedelai sebagai variabel dependen. Data yang digunakan dalam penelitian ini adalah data time series tahunan selama 34 tahun yaitu periode tahun 1980-2013. Data sekunder diperoleh dari lembaga serta instansi terkait seperti Badan Pusat Statistik, Departemen Pertanian, Food and Agriculture Organization, hasil penelitian, jurnal, literatur serta instansi lainnya yang terkait dengan penelitian ini.

\section{Model Analisis Data}

Model analisis untuk menguji pengaruh faktor-faktor permintaan kedelai di Indonesia menggunakan analisis regresi linier berganda yang telah ditransformasi kedalam bentuk logaritma dengan persamaan sebagai berikut:

$$
\log Q_{d}=\log a+b_{1} \log H_{k l}+b_{2} \log H_{k i}+b_{3} \log H_{a}+b_{4} \log Y+b_{5} \log T_{i}+D+e
$$

\section{Dimana :}

Qd : Permintaan kedelai

a : Konstanta atau intersep

Vol. 2 No. 2 Februari 2019 


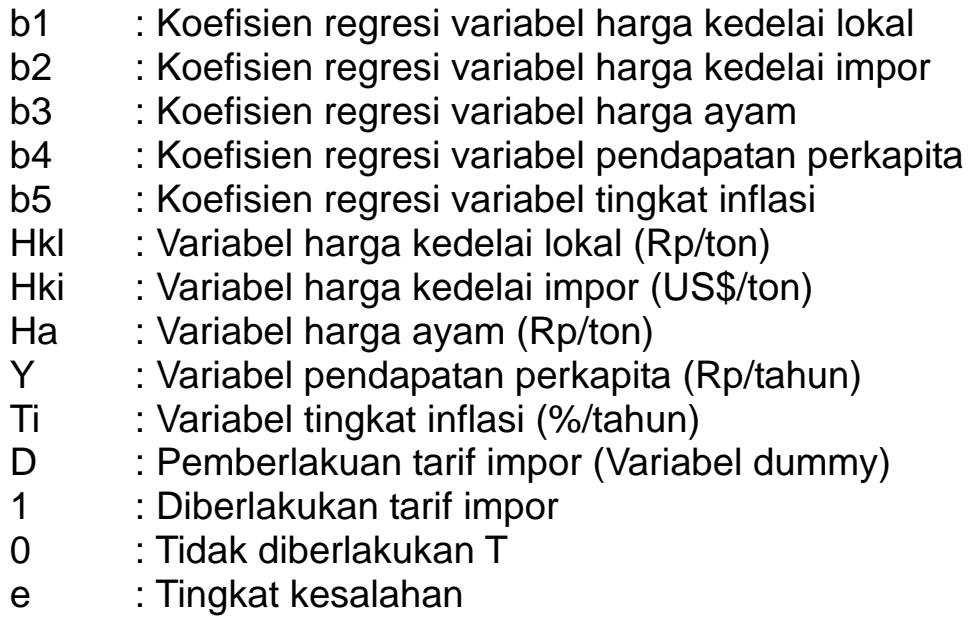

Persamaan diatas diestimasi dengan menggunakan metode Ordinary Least Square (OLS) dengan pengujian statistic melalui Uji t dan Uji F serta memperhatikan kemungkinan terjadinya penyimpangan asumsi klasik yaitu multikolinearitas heteroskedastisitas dan autokorelasi

\section{F. HASIL DAN PEMBAHASAN}

Hasil

Hasil analisis regresi pada tabel.1 menunjukkan bahwa variabel independen(harga kHasil analisis regresi pada tabel.1 menunjukkan bahwa variabel independen (harga kedelai,harga lokal,harga kedelai impor,harga daging ayam,pendapatan perkapita,tingkat inflasi, dan tarif impor)berpengaruh terhadap variabel dependen(permintaan kedelai)

Hasil analisis pada tabel.1 diperoleh nilai F-hitung sebesar 8,406 dan nilai tersebut lebih besar dari nilai F-tabel $(2,460)$ sehingga persamaan yang digunakan adalah linear. Hal ini berarti bahwa variabel independen secara bersama-sama berpengaruh signifikan terhadap permintaan kedelai pada tingkat kepercayaan $95 \%$.

Pada hasil regresi diperoleh nilai $\mathrm{R}^{2}$ sebesar 0,651 . Hal ini berarti bahwa $65,1 \%$ variasi variabel dependen (permintaan kedelai di Indonesia) dapat dijelaskan secara bersama-sama oleh variabel independen yang diteliti.sedangkan sisanya sebesar $34,9 \%$ dijelaskan oleh variabel lain yang tidak diteliti pada penelitian ini seperti selera, jumlah penduduk distribusi pendapatan dan lain-lain.

Tabel,2 Hasil analisis regresi permintaan kedelai di Indonesia

\begin{tabular}{lcc|c|c|}
\hline Variabel independen & Koefisien regresi & T-hitung & Signifikan & DW \\
\hline Konstanta & 0,412 & 0,349 & 0,730 & 2,018 \\
Harga kedelai lokal & 0,035 & 0,771 & 0,447 & \\
Harga kedelai impor & $-0,218$ & $-1,320$ & 0,198 & \\
Harga daging ayam & $-0,283$ & $-2,272$ & $0,031^{*}$ & \\
Pendapatan perkapita & 1,421 & 4,424 & $0,000^{*}$ & \\
Tingkat inflasi & $-0,227$ & $-2,416$ & $0,023^{*}$ & \\
Penetapan tarif impor & $-0,07$ & $-1,253$ & 0,221 & \\
(dummy) & \multicolumn{4}{c}{$\mathrm{dL:}, 1,079$} \\
\hline Koefisien determinasi $\left(\mathrm{R}^{2}\right)$ & 0,651 &
\end{tabular}




\begin{tabular}{|l|c|l|l|l|}
\hline F hitung & 8,406 & & & dU: 1,891 \\
\hline
\end{tabular}

Keterangan: *signifikan pada taraf kepercayaan 95\%

Pembahasan

Harga kedelai lokal

Koefisien variabel harga kedelai lokal tidak menunjukkan adanya pengaruh yang signikan terhadap permintaan kedelai. Nilai koefisien regresi variabel harga kedelai lokal sebesar 0,035 menunjukkan bahwa apabila harga kedelai lokal meningkat sebesar 1 persen maka permintaan kedelai hanya meningkat sebesar 0,03 persen. Hal ini menunjukkan tinggi atau rendahnya harga kedelai lokal tidak berpengaruh secara signifikan terhadap permintaan kedelai di Indonesia.

Permasalahan utama pada komoditas kedelai di Indonesia adalah tingginya jumlah konsumsi yang tidak sebanding dengan jumlah produksi. Sehingga menyebabkan pemerintah mengambil langkah kebijakan impor untuk menjaga stabilitas harga kedelai dalam negeri. Disamping jumlah penduduk yang terus bertambah setiap tahun, tingkat konsumsi semakin meningkat dan semakin banyak pula kedelai yang dibutuhkan. Untuk memenuhi tingkat permintaan yang tinggi tersebut dibutuhkan kedelai yang pemenuhannya lebih dominan dipenuhi oleh kedelai impor. Disebabkan defisit kedelai yang masih terus terjadi, harga menjadi hal yang tidak terlalu berpengaruh terhadap jumlah permintaan.

\section{Harga kedelai impor}

Variabel harga kedelai impor menunjukkan pengaruh yang tidak signifikan terhadap permintaan kedelai di Indonesia. Sebab, apabila Indonesia mengurangi jumlah impor sedangkan konsumsi kedelai terus meningkat dan produksi dalam negeri tidak dapat memenuhi kebutuhan konsumsi tersebut, maka defisit kedelai akan terus meningkat dan menyebabkan instabilitas harga yang juga akan berdampak pada stabilitas nasional. Besarnya ketergantungan Indonesia terhadap impor kedelai menyebabkan harga tidak menjadi pengaruh yang signifikan. Berapapun harga kedelai impor, jumlah kedelai yang diminta akan terus meningkat seiring jumlah penduduk yang terus bertambah dan kesadaran masyarakat akan bahan pangan yang bergizi serta terjangkau. Berbeda hal nya jika produksi dalam negeri mampu mencukupi kebutuhan konsumsinya sendiri dan tidak tergantung pada kedelai impor. Harga kedelai impor akan berpengaruh jika harga dunia lebih rendah dari biaya produksi. Sehingga tonggi atau rendahnya harga kedelai impor tidak akan berpengaruh terhadap permintaan kedelai di Indonesia.

\section{Harga Daging Ayam}

Hukum permintaan suatu barang berlaku bahwa perubahan harga suatu barang menyebabkan perubahan jumlah barang yang diminta. Hasil analisis regresi menunjukkan bahwa variabel harga daging broiler memperlihatkan pengaruh negatif dan signifikan terhadap permintaan kedelai pada tingkat kepercayaan 95\% dengan nilai koefisien regresi sebesar $-0,283$. Hal ini menunjukkan bahwa apabila harga ayam meningkat sebesar $1 \%$ dengan asumsi faktor lain dianggap tetap, maka permintaan kedelai di Indonesia akan mengalami penurunan sebesar $0,28 \%$. Hal ini menunjukkan bahwa hubungan antara ayam dan kedelai bersifat komplementer. Nilai elastisitas dari variabel harga daging ayam adalah sebesar 0,28 yang berarti daging ayam merupakan barang komplementer.

Variabel harga daging ayam juga berpengaruh signifikan dengan tingkat signifikansi 0,031 (taraf nyata 95\%) terhadap permintaan kedelai. Hal ini menjelaskan 
bahwa variabel tersebut berpengaruh nyata secara spasial dan dapat menjelaskan permintaan kedelai di Indonesia. Artinya tinggi rendahnya harga daging ayam akan sangat mempengaruhi permintaan kedelai di Indonesia.

Dewasa ini daging ayam tidak lagi menjadi barang substitusi bagi komoditi kedelai. Disamping kebutuhan gizi yang telah cukup terpenuhi, peningkatan pendapatan juga menjadi salah satu berubahnya pola konsumsi masyarakat. Laju ratarata pertumbuhan pendapatan yang lebih tinggi dibandingkan tingkat konsumsi membuat masyarakat mengganti pola konsumsi dengan bahan pangan yang lebih bergizi. Jika pada tahun 1960-an kedelai telah mencukupi sebagai panganan tambahan (lauk), maka saat ini bahan pangan kedelai saja tidaklah cukup untuk memenuhi kebutuhan pangan masyarakat. Dibutuhkan bahan pangan lain sebagai tambahan konsumsi sehari-hari.

\section{Pendapatan Perkapita}

Salah satu faktor penentu dalam permintaan suatu barang adalah pendapatan. Untuk barang normal berlaku hukum apabila pendapatan meningkat maka masyarakat akan meningkatkan jumlah permintaannya namun dengan persen yang lebih rendah dibandingkan dengan barang mewah atau superior(efek pendapatan positif).Sedangkan untuk barang inferior, apabila pendapatan meningkat maka masyarakat akan menurunkan jumlah permintaannya (efek pendapatan negatif). Hasil analisis regresi pada tabel. 1 menunjukkan bahwa pendapatan perkapita memiliki pengaruh yang signifikan terhadap jumlah permintaan kedelai di Indonesia pada tingkat kepercayaan 99\%.

Nilai koefisien regresi variabel pendapatan perkapita sebesar 1,421. Hal ini menunjukkan bahwa apabila pendapatan perkapita meningkat sebesar $1 \%$, maka permintaan kedelai akan meningkat sebesar $1,4 \%$. Nilai elastisitas dari variabel pendapatan perkapita adalah sebesar 1,421 yang berarti kedelai di Indonesia termasuk barang superior yang merupakan kebutuhan pokok.

Berdasarkan data pendapatan yang bersumber dari BPS, Indonesia mengalami peningkatan pendapatan perkapita setiap tahunnya. Meningkatnya pendapatan menjadi salah satu faktor berubahnya pola konsumsi masyarakat Indonesia. Jika dicermati, perhatian masyarakat terhadap konsumsi bahan pangan bergizi tinggi terus meningkat. Perubahan pola konsumsi dari karbohidrat tinggi dengan protein rendah menjadi pola konsumsi karbohidrat lebih rendah dengan protein yang lebih tinggi. Sehingga dengan adanya peningkatan pendapatan membuat masyarakat mengkonsumsi bahan pangan bergizi tersebut lebih dari biasanya, salah satunya adalah kedelai. Wajar bila saat ini kedelai menjadi barang yang superior, karena selain produk utama, kini juga banyak produk turunan yang ditawarkan dari komoditas kedelai yang tidak hanya menambah nilai ekonomi, namun juga menambah nilai gizi.

\section{Tingkat Inflasi}

Koefisien variabel tingkat inflasi menunjukkan adanya pengaruh negatif dan signifikan terhadap permintaan kedelai di Indonesia. Nilai koefisien sebesar $-0,227$ menunjukkan bahwa apabila inflasi meningkat $1 \%$ maka permintaan kedelai akan menurun sebesar $0,227 \%$ sedangkan faktor lain dianggap tetap.

Inflasi merupakan gejala yang menunjukkan kenaikan tingkat harga secara umum yang berlangsung secara terus menerus. Apabila kenaikan harga hanya bersifat sementara, maka kenaikan tersebut tidak dikatakan inflasi. Para ekonom berpendapat bahwa inflasi dapat dijadikan sebagai tolok ukur baik buruknya masalah perekonomian suatu negara. Keadaan menurunnya permintaan karena faktor inflasi disebabkan meningkatnya harga secara terus menerus. 
Disisi lain, pendapatan masyarakat yang cenderung stabil disaat harga terus meningkat tidak mampu mengimbangi kebutuhan akan konsumsi kedelai.Apabila dikaitkan dengan konsep elastisitas permintaan dimana harga barang yang meningkat akan menyebabkan permintaan menurun, maka peningkatan inflasi yang terus terjadi akan menurunkan daya beli masyarakat akan barang tersebut. Sehingga dapat disimpulkan bahwa inflasi dapat menurunkan permintaan kedelai di Indonesia.

\section{Kebijakan Tarif Impor (Variabel Dummy)}

Variabel dummy kebijakan tarif impor tidak menunjukkan adanya pengaruh yang signifikan terhadap jumlah permintaan kedelai di Indonesia. Dalam upaya menjaga stabilitas harga kedelai lokal, dengan tetap memperhatikan kepentingan petani dan konsumen, pada tahun 2013 pemerintah memberlakukan tarif impor (bea masuk) sebesar nol persen. Ketetapan ini tertuang dalam Peraturan Menteri Keuangan Nomor 133/PMK.011/2013 yang ditandatangani oleh Menteri Keuangan pada 3 Oktober 2013. Ketentuan tersebut sekaligus mengubah Peraturan Menteri Keuangan Nomor 213/PMK.011/2011 yang memberikan bea masuk sebesarv 5 persen atas impor kedelai. Adanya penetapan tarif impor seharusnya mampu menjaga keseimbangan antara pasokan impor dan produksi dalam negeri. Namun adanya pemberlakuan kebijakan tarif impor belum efektif dan efisien untuk menanggulangi permasalahan permintaan kedelai. Hal ini disebabkan ketergantungan pemerintah terhadap kedelai impor. Ketergantungan ini diakibatkan oleh kenyamanan pemerintah untuk terus mengimpor kedelai disaat produksi kedelai masih dapat dikembangkan. Besarnya ketergantungan terhadap impor berdampak pada tidak adanya upaya peningkatan produksi dan daya saing kedelai. Hal ini menyiratkan bahwa kebijakan tarif impor hanya menguntungkan pihak tertentu. Selain itu, faktor lain yang lebih berpengaruh terhadap permintaan kedelai diantaranya harga barang lain yang terkait, faktor selera dan lain-lain.

\section{KESIMPULAN DAN SARAN}

\section{Kesimpulan}

Permintaan kedelai secara bersama-sama dipengaruhi oleh harga kedelai lokal, harga kedelai impor, harga daging ayam, pendapatan perkapita, tingkat inflasi dan tarif impor. Secara parsial, harga kedelai lokal,harga kedelai impor dan tarif impor tidak berpengaruh signifikan terhadap permintaan kedelai, sedangkan harga daging ayam, pendapatan perkapita dan tingkat inflasi berpengaruh signifikan terhadap permintaan kedelai di Indonesia. Elastisitas pendapatan masyarakat Indonesia terhadap permintaan kedelai bernilai positif, sedangkan elastisitas harga silang dari kedelai yaitu daging ayam bernilai negatif yang berarti bahwa komoditi daging ayam bersifat substitusi bagi komoditi kedelai.

Saran

Dari kesimpulan atas hasil analisis penelitian ini, maka saran-saran yang dapat diajukan adalah sebagai berikut:

1. Pemerintah selaku pengampu kebijakan agar dapat mengendalikan kedelai impor serta mendorong para petani agar mampu memproduksi kedelai secara masal seiring permintaan yang terus meningkat melalui kebijakan-kebijakan yang menguntungkan petani dan masyarakat secara umum demi menjaga kestabilan perekonomian. 
2. Petani kedelai agar dapat meningkatkan keterampilannya dalam pengelolaan kedelai dengan menerapkan teknologi, metode ataupun bibit unggul yang dapat meningkatkan produksi serta produktivitasnya.

3. Instansi terkait agar dapat terus meningkatkan dukungannya bagi pengembangan usahatani kedelai

\section{G. DAFTAR PUSTAKA}

Food and Agriculture Organization.2012. Indonesia Soybean Import Quantity.

http://faosfat.fao.org.diakses pada 15 april 2015Departemen Pertanian. 2015. Perkembangan impor kedelai indonesia.http//database.pertanian.go.id. Diakses pada 15 Mei 2015

Direktorat Pangan dan Pertanian. (2013). Rencana Pembangunan Jangka Menengah Nasional (RPJMN) Bidang Pangan dan Pertanian 2015-2019.BAPENNAS. Jakarta.

Manurung, R.M.H. 2002. Tantangan dan peluang pengembangan tanaman kacangkacangan dan umbi-umbian hlm.19-40. Risalah Seminar Teknologi Inovatif Tanaman Kacang-kacangan dan Umbi-umbian Mendukung Ketahanan Pangan. Malang, 25-26 Juni 2003. Balai Penelitian Tanaman Kacang-kacangan dan Umbi-umbian, Malang.

Nopirin. 2009. Ekonomi Internasional. Edisi ketiga. BPFE. Yogyakarta.

Rante, Y., 2013. Strategi Pengembangan Tanaman Kedelai Untuk Pemberdayaan Ekonomi Rakyat Di Kabupaten Keerom Provinsi Papua. Jurnal Manajemen Keuangan, Vol.15. hlm.75-88.

Siregar, M. 2003. Kebijakan Perdagangan dan Daya Saing Komoditas Kedelai. PSE Balitbang Pertanian, Deptan RI. Bogor.

Sudaryanto, T.\& Swastika, D. K. S. 2007. Ekonomi Kedelai di Indonesia. Dalam; Sumarno, Suyamto, Widjono, A., Hermanto, K, H., (Eds). Kedelai: Teknik Produksi dan Pengembangan. Badan Penelitian dan Pengembangan Tanaman Pertanian. Bogor. 